\title{
The Influence of Tourism Towards the Dynamics of Women's Rights in Marriage Law in Bali
}

\author{
Ariani $^{1}$, Sukerti $^{2}$ \\ Faculty of Law \\ Udayana University \\ Bali, Indonesia \\ ,E-mail: agungariani1944@gmail.com
}

\begin{abstract}
This research aims to examine the influence of tourism on women rights towards the dynamics in marriage law in Bali by answering the questions: 1) How does tourism affect women empowerment, especially in marriage life; 2) By women participation in public sector of tourism, does it create the dynamics of women rights in marriage law in Bali? The method used in this research is empirical law research by interview method to informants and respondents with interview method, analysis data applied qualitatively. The research results showed that tourism has affected on women empowerment. Women can fill job opportunities and business opportunities in the tourism sector either as worker, as independent entrepreneurs or as workers/ entrepreneurs to help their husbands. Oftentimes, women in research villages do multiple livelihood patterns. Women have their own income to increase their personal resources and sustain the familyeconomy, women are not dependent on men as stereotype that have been existed. Tourism also has a real significant effect on women rights dynamics, where women as workers, independent entrepreneurs, workers/entrepreneurs to help their husbands have authority to manage business by autocratic and syncretic decision making pattern which is indicating that women are participating, has rights in decision making.
\end{abstract}

Keywords: Tourism, Dynamics, Women’s rights, Marriage, Bali.

\section{INTRODUCTION}

Fundamentally, every single human was born free and equal. Men and women have the same rights and opportunity in any aspects in their life and in any fields of development. It has been stated clearly in Law Number 39/ 1999 on Human Rights, Article 3 Paragraph 1, stated that: "Every human being was born free and own equal dignity and entitled to live in society, nation and state in the spirit of brotherhood."

In reality, the biological differences between men and women has created the classification of working sexually, place women in domestic domain, men in public domain that affects to the emergence of gender stereotype, men are superior and women are inferior. It brings the women in unfavorable circumstance in any aspects of life both within their family and also society. Women are relying on men, creates unequal gender relation that cause harassment towards women. By becoming the public tourism object since 1970s with NgurahRai as the international airport, it also opens wider job and business opportunity for all society, including women. It creates the wider opportunity for women to work in public sector. By working in public sector, it increases their involvement in the society outside their family and they also make money and increase her personal capability. In the other hand, women are still concerned with the social and culture aspect, which is the patriarchy system in customary law that limits women's rights in family and marriage. According to that background, find out the answer regarding how tourism affects the women empowerment and the dynamic of women right in marriage life is needed.

\section{RESEARCH METHOD}

Legal research is divided into doctrinal/ normative legal research and non-doctrinal/ empirical legal research. This research is non-doctrinal/ empirical legal research which used field data as primary data. Types of data on this research are primary and secondary data. The primary data was collected from the field research at District of KutaBadung Regency and District of Ubud-Badung Regency. The data was obtained by interviewing the respondents and informants deeply using guide interview. The informants are leaders in the region where the research took a place to get initial information about the tourism development and information from married couple who work in tourism sector. The secondary data was from literature research and documents that is related with the issue, such as primary legal materials: Law No.1/ 1974 on Marriage, Law No.7/ 1984, Law no. 39/1999 on Human Rights, previous 
research, documents related to Balinese Customary Law such as Manawa Dharmasastra, as well as other secondary Legal Materials. District of Ubud's data in form of numbers, the monograph of Ubud and data of District of Kuta. All data were processed and qualitatively analyzed from gender perspective and will be presented descriptively analytical.

\section{RESULT AND DISCUSSION}

\subsection{Research Result}

3.1.1 The Influence of Tourism on Community Empowerment in the Research Village

Tourism sector has very significant effect to the community in the research village. People in district of Kuta perceive if tourism is "PayukJakanMasyarakatKuta" means Kuta as main source of livelihood for society, as the key of economy, not only for society in District of Kuta but also for society outside Kuta, many people work in there. The result of Strategic Structural Plan for Kuta in 2002, estimated 57.000 people in and out at Kuta every day. For the total number, 5.000 are taking a trip across Kuta, 3.000 are on vacation, and 49.000 are working and doing business. Meanwhile, the total of job field, which can absorb worker in Kuta, estimated 30.000 people.

As tourism destination, District of Kuta has various facilities for tourism. In 2016, the total of accommodation/ hotel consist of: 107 budget hotels as the biggest number, 26 one star hotels, 24 two stars hotels, 19 three stars hotels, 26 four stars hotels, 23 five stars hotels, 63 restaurants, and any other facilities such as: discotheques, karaoke, billiards, pubs, and other entertainments. The district of Kuta with its traditional village provides those facilities in managing the tourism and it has positive impact for the traditional village's income with various body such as: Beach Management Unit of Kuta Traditional Village that manages the Kuta Beach properly by supervising all tourism activities at the beach so it's still safe and sustainable as public area and holly area. For the cleanliness at beach area, The Traditional Village hired 65 women worker in various age, included elderly with aroundRp.1.600.000,00/person/month as the wage. The Traditional village also manage Kuta Art Market by contract system for the seller, and it prioritizes local with rent money around Rp.350.000,00/month, shops contracting management, manage karma tamiu (immigrant) by paying Rp.75.000,00/ 3 months. To maintain the Traditional Village' finance, they established Village Finance Management Board, located in the Village Credit Institution Office (LPD) and also the Asset Management of Traditional Villages of Kuta. By the management of traditional village of Kuta through LPD they can subsidize various activities that needs aid based on needs and capability of the traditional village and even has given subsidy to village community when they held joint ceremony/ yadnya (charity)such as Pitra Yadnya Ceremony/ Ngaben/ Ngerit (Balinese Traditional Cremation), so that helps village community burden.
The positive influence from tourism can be seen clearly from its income. The monograph data of District of Ubud shows the income from the accommodations/ hotels results highest number: P 116.937.120.000,00; trading sector: 75.650.000.000,00; service sector: 8.366.280.000,00; Agriculture sector: 5.066.482.600,00; tourism sector 1.926.510.200,00; home industry: 1.038.000.000,00 and the lowest number is livestock: only $156.000 .000,00$. It shows if there is the shifting of livelihoodfrom agriculture sector to tourism sector that has dominated the livelihood and the income of the society so far.

\subsubsection{The Influence of Tourism on Women Empowerment in Marriage}

What it means by women empowerment iswhere women make a movement by themselves because they face a challenge. The notion of empowerment means the changing of women's state of mind. Empowerment also means that women have skill and capability to improve the independence and power within themselves and not to dominate others/ men. Empowerment is all activities that have been done by women directly or indirectly, to liberate them from being dependence of other people, men or their husband. Empowerment is based on cooperation to reach the collective goals with reciprocity that empowers both men and women.

The result shows the increasing of tourism gives more business opportunity and job fields, in more various form included for women. When observing more on the participation of women in research village, women are more likely to respond to existing job opportunities that do not require special skills, such as: the seller of foods, drinks or art, souvenirs, clothes, seller in art market, traditional massage on the beach, hair braiding, employee in private company, such as: spa, salon, inn, restaurant, café, money changer, homestay, hotel, bungalow, villas and other tourism facilities. Men and women have done multi role and double income job, fulfill the job and business opportunity. Women do more than one type of jobs. The increasing of various jobs can improve the tourism facilities, but in the other hand it creates the job opportunity for women as srati banten in tourism business by receiving Rp.2.000.000,00 until Rp.2.500.000,00/ month as their wage and depends on the amount of offering that buyer needs. Because society is busy to do activities in business and other activities, there are also other occupations appear for women to do individually or collectively as banten/sajen (offering) maker, starts from small size until medium size, to fulfill the needs of society for praying. For those who are not able to make the offering by themselves, they simply will just order the offering to the offering maker. Therefore, they can still do their business or occupation and the ceremony as well and even create the job field for other women. There is also catering business by women to provide meals for people who held the ceremony in any form and level of ceremony so that this will create more various form of jobs. 
Furthermore, how tourism affetcs on women empowerment in marriage life will be observed deeper in married couple participation in tourism activity. It can be seen from the job status, from 25 women as respondents they are classified into: 1) Both wife and husband have their own separate business, 15 respondents. 2) Both wife and husband work together in tourism sector, 7 respondents. 3) Wife is working in non-tourism sector to help the husband who works in tourism sector, 3 respondents.

Hence, the participation of women in tourism sector as entrepreneur, joint business with husband, and help the husband. For entrepreneur job status, women have the autonomy to manage the business, means all buying-selling transaction, materials for business fulfillment and transaction with other people, will be done by women/ wife. For joint business with husband, the data shows there are many developed businesses in Kuta and Ubud where husband handed some parts of business to their wife. The wives manage the business (homestay, art shop, hotel, villa, restaurant, café, store) while the husbands supervise and manage other matters (the store and land rent, and other bigger matters such as: manage a museum). For the business which are managed by wives, they will manage the income from the business that will be used for operational fees, business expansion, daily family needs, social activity (menyama-braya), saving, investment and other bigger expenditure will be done by both wife and husband. For wives who help the husbands, most of business activity will be managed by the husbands and wives will only help the husbands. From those three classifications, it shows the role of men as husbands is dominating the ownership of business.

\subsubsection{The Influence of Tourism on the Dynamics of Women's Right in Marriage Law}

Women's rights in this research means the rights that emerge as the cause of legal ties between wife and husband in the family and its wealth of marriage. A family is formed by the occurrence of marriage. Marriage is the physical and spiritual bonding between a man and a woman as husband and wife in order to establish a happy and everlasting family (home) based on "In the One and Only God" (Art. 1) Law No. 1/ 1974 on Marriage. To actualize a happy family needs material basis for family in a form of wealth and assets. According to the customary law, the assets of marriage is not a single asset, it depends on the process of marriage, the type and origin of the assets. Family wealth/ marriage assets included the assets of the husband, the assets of the wife and the joint assets (gono-gini) of both husband and wife. Based on Balinese customary law, the circumstance is not much different. The family wealth is included: 1) the assets or wealth that brought by husband or wife into the marriage from respective parents which is called tadtadan, bebaktan, ketipatan as the form of the soul of funds; 2) the assets or wealth that brought by husband or wife into marriage derived from their respective business or livelihood before marriage which is called akas kaya; 3 ) the assets or wealth acquired by husband and wife after and during marriage which is called guna kaya; 4) the assets or wealth earned by husband or wife for her own business during the marriage time, which is also known as akas kaya. From those kinds of assets, how does woman get her rights in owning the assets and wealth? According to old norms or the old culture of law, a woman as a wife should not act independently without the consent of her father or husband, as in the Law of HindhuManawa Dharmasastra Chapter V-149: as a wife and as a woman, she should be able to try not to act alone by abandoning his father or husband.

In analyzing the rights of women in marriage life, it is necessary to use common analysis in women study that follows the decision making from the husband-wife in family/ marriage life. Herbst statement that has been improved by T.O. Ihromi, stated that the interaction in marriage life consists of dimension of activity and dimension of decision. The dimension of activity and decision are measured by who undertakes the action and who makes the decision regarding the action, by arranging the typology of marital power, there are: the husband dominance, the wife dominance, autonomic and syncretic.The pattern of interaction autonomic/ autocratic is when the decision regarding the action is taken by either husband or wife, without depending on each other, while the pattern of interaction syncretic is when the decision was taken by both husband and wife.

Regarding the rights of women in the marriage life, and stipulated by Law No.1/ 1974, it is regulated the power of marriage in Chapter VI Articles 30 to 34, on the Rights and Responsibility of Husbands and Wives, stated: The rights and the position are equal and each party may exercise legal attempt (Article 31 Paragraph 1 and 2). The husband is the head of family and the wife of the housewife (Article 31 Paragraph 3 Article 34 Paragraph 1) stipulated that: the husband is obliged to protect his wife and provide all household necessities based on his capability, and the wife is obliged to manage the household affair as good as possible. This condition seems good on managing a balance power between husband and wife, but on the other hand, it is still labelling women for only managing the household or domestic duties at their best, while husband can manage anything outside the domestic affair based on their capability. Thus, this condition substantially remains gender bias.

Hereinafter, in association with family wealth/ marriage wealth in Law No. 1/ 1974 also has been regulated which is not much different from the customary law that, there are: 1) joint wealth or assets acquired by husband and wife during marriage (Article 35 paragraph 1). 2)the wealth or assets from husband and wife acquired as a gift or inheritance, it is under their control as long as the parties do not specify otherwise. Based on the form of family assets, it can be distinguished as: 1) conventional assets is the wealth that has high value such as land: yard land, living place, rice field, lea, jineg or gelebeg; 2) contemporary assets: wealth which are obtained according to current developments: companies, hotels, inns, stores, household appliances, TVs, cars, motorcycles, jewelry, and other 
moving goods. By the new arrangements in marriage law and bythe increasing of women participation in the public sphere/ tourism, what is the contribution of women in gaining wealth and what are the benefits and how to managethe wealth and decision-making.

The result shows that the hereditary wealth in marriage, such as inheritance or gifts are simply tangible contemporary wealth, most moving goods like jewelry, clothing, motorcycles, saving, household appliances. Women do not get conventional wealth in the form of land. Land is the most valuable asset and increase the prestige of the family. It happens because according to Balinese customary law women are not heirs. Men/ husbands are more likely to get conventional assets in the form of land, derived from the inheritance of their parents, at least the yard of the place of living, because men are the heirs and the successors of rights and obligations of family. This is related to the custom of settling after marriage where women will follow husbands and reside at the husband's family residence (patriarchy). This yard of living is usuallymanaged to be homestay as a start of their business in the research village. The joint assets will be obtained from the business during the marriage whether the status of business is separate business of husband and wife, joint business of husband and wife and wife who helps the husband's business. The income management of this business has two methods, there are: 1)married couple manage to take the income separately; 2) married couple manage to pool the income or income pooling as well as the business activities are managed by each husband and wife in a joint business status which gives the autonomy for wife to manage certain part of their business, so the management/ the ownership of income also becomes the autonomy of each husband and wife and in certain cases they can be combined for greater expenditure. For the wife's business status to help the husband the management of income is dominantly on the husband's hand. Thus women have the right or power to make decisions for the use of such income, for example: the cost of family necessary(daily necessities, family routine ceremonies), social activities (menyama-braya), for business development, the purchase of contemporary wealth (cars, motorcycles), investment for those who are able, savings/ deposits, and conventional wealth (land). The decisionmaking will be on women's hand/ autocratic and to buy land the decision will be done together/ syncretic. When traced deeper on behalf of the purchase of such assets, for conventional property of land, for a (very successful) family, it is agreed under the name of a wife, or under the name of the husband, yet still dominant under the husband's name, as well as contemporary wealth. This indicates that women have the right to make decisions and become owners of the assets, thus also means the dynamics of women rights exist.

\subsection{Discussion}

According to the explanation above, it shows that women participate in tourism sector, it means that women not always work at home as what the stereotype of classifying the work based on gender when women should stay at home and men work in public sector has existed. It also indicates that women have their capability to be empowered in public sphere, business sector, and not only as the worker but also as a good and independent owner, together with her husband or help her husband. Women have the autonomy to manage a business and the income from the work to fulfill her own needs, become independent and have her own power, quite capable in helping the economy of her family, and also support the continuity of family's life. Women also contribute towards family wealth/ marriage assets. Women is not a dependent actor and men as the head of family do not need to fulfill his family needs by himself. It seems that the condition has shifted into condition where between husband and wife help each other, men and women for family financial as the collective empowerment in establishing happy family.

If we observe deeper from the ownership of business, there are business under wife's name, even though the ownership of husband remains dominant. Regarding the form of family wealth such as inheritance, wives only carry the contemporary assets, and do not carry any conventional assets like land which was the most valuable wealth before tourism. Balinese custom law remains strong patriarchy system which is glorifying the capability of men instead of women, so that the husbands are more likely to get land as the conventional wealth. By the possibility of making decision of women (autocratic) in dealing with income from the business, making decision to buy contemporary or conventional assets for a settle family and the possibility to be the ownership of certain assets, it means there is a changing or dynamic of women right in marriage law where the old norms stated that woman cannot act by herself without the involvement of her father or husband. The issues of marriage assets and the ownership are big matters for married couple, if in the future undesirable case happen, like divorce, this will not harm one party only, especially women. The existence of objective conditions in the ownership of business and income remains husband as dominant actor, this is as cultural consequences of patriarchy system, where it is substantively perpetuated in marriage law stated: "husband as the head of family, and wife as the housewife (article 31, paragraph 3) ". Where this provision is very inconsistent with the previous provisions that have provided a balance position between husband and wife. Therefore, this article needs to be revised with the provision that family responsibilities are the responsibility of the husband and wife in accordance with the objectives of women empowerment to achieve gender equality and justice between men and women.

\section{CONCLUSION}

Tourism affects the empowerment of women in marriage life, especially in economy sector, either directly or indirectly affected. Women have personal capability to increase their independence and their own strength, can 
contribute to family wealth. The occurrence of changes or dynamics of women's rights from the previous norms in which women have the power/ autonomy in managing the business and income with the pattern of decision-making autocratic and syncretic and can be an owner of family assets both contemporary and conventional, but on the other hand still feels the dominance of husbands in the management of business, ownership and family assets, as a result of patrilineal and patriarchal society and the existence of substantive legal provisions are still gender bias.

\section{ACKNOWLEDGEMENT}

Various contributions have involved in the writing of this research. The researcher would like to thank the Rector of Udayana University, the Dean of the Udayana University Faculty of Law for the permission and funding provided for this research. Institute of Research and Community Service of Udayana University, Head of National Unity and Politics Unit of Badung Regency and Gianyar Regency, Head of Kuta Village, Kuta Sub-district, Regency of Badung, Head of Ubud Village, Ubud District, Regency of Gianyar, to informants and respondents who have provided very useful data information related to this research. Likewise to the field workers/ field officers for their effort to help collecting data, they are: Owen as bachelor student, Agung Eka Maharta as magister student, Ni Nyoman Sri Susilawati as doctoral student. Faculty of Law of Udayana University, once again we are deeply thankful.

\section{REFERENCES}

Adi, Ida Bagus Ngurah ,1973,Harta perkawinan Menurut HukumAdat Bali, in Lembaga Pembinaan Hukum Nasional Magazine

Ihromi,T.O., 1992, Otonomi Wanita, dalam Antropologi Indonesia, Antropologi Sosial dan Budaya Indonesia Magazine, No.50, Year. XV, September - December 1992, Department of Anthropology, Faculty of Social and Political Science, University of Indonesia

Keiyuciving ,Grace F, 2008, in Komariah Emong Sapardjaja, (Editor), Kompendium Tentang HakHak Perempuan, Badan Pembinaan Hukum Nasional, Department of Law and Human Rights Republic of Indonesia.

Sub-District of Kuta, District of Kuta, Regency of Badung, Bali Province, 2010, Kuta Kita, Catatan Kecil Kuta Membangun

The Ministry of Women Empowerment of Repubic of Indonesia, 2005, Profil Gender Tenaga Kerja Sektor Pariwisata di Propinsi Bali, Coorperated by
Center of Women Study, Udayana University, Denpasar

Mukti Fajar, Yuliani Achmad, 2010, Dualisme Penelitian Hukum Normatif dan Empiris, Publication.I, Pustaka Pelajar Yogyakarta

Pudja,Gede, Tjokorda Rai Sudharta, 1975, Manawa Dharma sastra (WedaSmrti), Jakarta: Parisada Hindhu Dharma Pusat

Sitorus ,M.T. Felix, 2000, HakWarisJanda Dan Anak Perempuan Batak Toba Masa Kini, dalam Hukum dan Kemajemukan Budaya ,E.K.M. Masinambow (ed), Jakarta: YayasanObor

Soerjono Soekanto,2001, Hukum Adat Indonesia, Cet.4, Jakarta:Yayasan Obor Indonesia

Sunggono,Bambang, 2006, Metodologi penelitian hukum, Pt Raja Grafindo Persada, Jakarta

Supomo, 1963, Bab - Bab Tentang Hukum Adat, Penerbit: Universitas. 